\title{
Local Circuit Interactions Between Oriens/Alveus Interneurons and CA1 Pyramidal Cells in Hippocampal Slices: Electrophysiology and Morphology
}

\author{
Jean-Claude Lacaille, ${ }^{1}$ Alan L. Mueller, ${ }^{1, a}$ Dennis D. Kunkel, ${ }^{1}$ and Philip A. Schwartzkroin ${ }^{1,2}$ \\ Departments of ${ }^{1}$ Neurological Surgery and ${ }^{2}$ Physiology and Biophysics, University of Washington, Seattle, Washington \\ 98195
}

Electrophysiological and anatomical techniques were used to determine the role, in the hippocampal circuitry, of local circuit neurons located at the oriens/alveus border (O/A interneurons). Intracellular recordings from these cells showed that their response characteristics were clearly nonpyramidal: high input resistance, short membrane time constant, short-duration action potential, pronounced, brief afterhyperpolarizations (AHP), and nondecremental firing during intrasomatic depolarizing current pulses. Intracellular Lucifer yellow (LY) injection and subsequent fluorescence microscopy confirmed their nonpyramidal nature. $\mathrm{O} / \mathrm{A}$ interneuron somata were bipolar or multipolar; their dendrites projected mostly parallel to the alveus, except for 1 or 2 processes that turned perpendicularly, and ascended through stratum oriens and pyramidale and into radiatum. Their axons were seen to branch profusely in stratum oriens and pyramidale. Simultaneous intracellular recordings from $\mathrm{O} / \mathrm{A}$ interneurons and CA 1 pyramidal cells showed that pyramidal cells directly excite these interneurons. Major hippocampal afferents also directly excited the O/A interneurons. In a small number of interneuron-pyramidal pairs, stimulation of the $\mathrm{O} / \mathrm{A}$ interneuron directly inhibited pyramidal cells. In one case, reciprocal connections were observed: The pyramidal cell excited the interneuron, and the interneuron inhibited the pyramidal cell. In 1 interneuron-to-interneuron pair, an inhibitory connection from $\mathbf{O} / \mathrm{A}$ interneuron to stratum pyramidale interneuron was also observed. With intracellular HRP injections into O/A interneurons and subsequent electron microscopy, we observed that $O / A$ interneuron axons made contacts with pyramidal and nonpyramidal cells. HRP-filled symmetric synaptic contacts were found on pyramidal cell dendrites and somata. HRP-filled axons also made contacts with pyramidal cell initial segments. HRP-filled $\mathrm{O} / \mathrm{A}$ interneuron axon contacts were also found on nonpyramidal cell dendrites in stra-

\footnotetext{
Received July 14, 1986; revised Jan. 12, 1987; accepted Jan. 20, 1987.

This work was supported by National Institutes of Health, National Institute of Neurological and Communicative Disorders and Stroke Grants NS 15317, NS 00413, NS 18895, and Natural Science Foundation Grant BNS 8209906 . J.-C.L is the recipient of a NATO Science Fellowship from the National Sciences and Engineering Research Council of Canada. A.L.M. is the recipient of a National Research Service Award Postdoctoral Fellowship (NS 07012). P.A.S. is an affiliate of the Child Development and Mental Retardation Center, University of Washington.

Correspondence should be addressed to Professor Schwartzkroin at the above address.

a Present address: Abbott Laboratories, Dept. 47H-APl0, Abbott Park, IL 60064. Copyright (C) 1987 Society for Neuroscience $0270-6474 / 87 / 071979-15 \$ 02.00 / 0$
}

tum oriens. These electrophysiological and anatomical results suggest that $\mathbf{O} / \mathbf{A}$ interneurons make synaptic contact with pyramidal cells and may mediate feedforward and feedback inhibition onto CA1 pyramidal cells.

The hippocampal formation is comprised of 3 main cell groups: the granule cells of the dentate gyrus and the pyramidal cells of the CA3 and CA1 regions (Ramon y Cajal, 1911; Swanson and Cowan, 1977). Their lamellar trisynaptic organization has been described in detail (Ramon y Cajal, 1911; Andersen and Lomo, 1966; Andersen et al., 1966, 1971, 1973; Blackstad et al., 1970; Lomo, 1971; Hjorth-Simonsen, 1973). In addition to these principal cells, many types of polymorph intrinsic neurons (interneurons) are present in the hippocampal formation (Ramon $y$ Cajal, 1911; Lorente de No, 1934; Amaral, 1978; Somogyi et al., 1983). Apart from 1 type of interneuron, the so-called basket cells, combined physiological and morphological evidence of the way in which these local circuit neurons influence transmission through the principal trisynaptic circuit is, for the most part, lacking.

The basket cells are located at the stratum pyramidale/stratum oriens border of CAl (Ramon y Cajal, 1911; Lorcnte de No, 1934; Schwartzkroin and Mathers, 1978; Schwartzkroin and Kunkel, 1985) and have axon collaterals ramifying in a dense basketlike plexus around pyramidal cell bodies (Ramon y Cajal, 1911; Lorente de No, 1934). They appear to use GABA as neurotransmitter (Ribak et al., 1978; Ribak and Anderson, 1980; Kunkel et al., 1986), and they make synaptic contacts with pyramidal cell somata (Schwartzkroin and Kunkel, 1985). They are strongly excited by pyramidal cells, and, in turn, they directly inhibit pyramidal cells (Knowles and Schwartzkroin, 1981). In addition, they receive direct excitatory input from afferents coursing through strata radiatum and oriens (Frotscher et al., 1984; Schwartzkroin and Kunkel, 1985). Thus, these basket interneurons have been suggested to mediate feedforward and feedback inhibition of pyramidal cells (Knowles and Schwartzkroin, 1981; Schwartzkroin and Kunkel, 1985).

There is much less evidence, however, about the function of the other types of interneurons. In order to further determine the role of interneurons in the local circuitry of the hippocampus, we have focused our attention on a distinct group of interneurons that are localized at the stratum oriens/alveus $(\mathrm{O} /$ A) border. Using Golgi stains, Ramon y Cajal (1911) and Lorente de No (1934) identified and described these neurons and their extensive axonal ramifications in stratum oriens, pyramidale, and radiatum. Recently, neurons similarly located at 
the O/A border have been shown to contain somatostatin (somatotropin release inhibiting factor; SRIF)-like immunoreactivity (Kohler and Chan-Palay, 1982; Morrison et al., 1982; Roberts et al., 1984; Bakst et al., 1985) and also colocalize glutamic acid decarboxylase (GAD) immunoreactivity (Somogyi et al., 1984). Physiological effects of SRIF on hippocampal pyramidal cells, although inconsistent, have also been described (Dodd and Kelly, 1978; Pittman and Siggins, 1981; Mueller et al., 1986). Thus, the oriens/alveus interneurons may directly affect pyramidal cells and may use SRIF and/or GABA as a neurotransmitter.

We have used electrophysiological and morphological approaches in hippocampal slices of guinea pigs to obtain direct evidence regarding the role of these interneurons in the hippocampus. We report here the intracellular response properties of these neurons and their interactions with pyramidal cells. We describe their morphology, as seen following intracellular Lucifer yellow injection. We also report that at the ultrastructural level, HRP-filled O/A interneuron axons make contacts with pyramidal and nonpyramidal dendrites and somata.

\section{Materials and Methods}

Experiments were performed using hippocampal slices from Hartley guinea pigs $(200-400 \mathrm{~g})$ maintained in vitro, as previously described (Schwartzkroin, 1975, 1982; Mueller et al., 1984). Animals were decapitated, and the hippocampus was rapidly dissected free. Transverse hippocampal slices (450-500 $\mu \mathrm{m}$ thick) were cut on a McIlwain-type tissue chopper. For some experiments, longitudinal slices $(500 \mu \mathrm{m}$ thick) were obtained from the middle half of the hippocampus. Slices were immediately transferred to an incubation chamber, where they lay on a Nylon mesh grid at a fluid-gas interface. The bathing medium, which contacted the slices at their undersurfaces, was composed of $124 \mathrm{~mm}$ $\mathrm{NaCl}, 5 \mathrm{~mm} \mathrm{KCl}, 1.25 \mathrm{~mm} \mathrm{NaH}_{2} \mathrm{PO}_{4}, 2 \mathrm{~mm} \mathrm{MgSO}_{4}, 2 \mathrm{~mm} \mathrm{CaCl}, 26$ $\mathrm{mm} \mathrm{NaHCO}_{3}$, and $10 \mathrm{~mm}$ dextrose. Slices and medium were maintained at $35 \pm 0.5^{\circ} \mathrm{C}$ with a feedback control system. Bathing medium was oxygenated with $95 \% \mathrm{O}_{2} / 5 \% \mathrm{CO}_{2}$, and the atmosphere above the slices was kept warm, moist, and oxygenated.

Intracellular recordings. Intracellular recordings were obtained with micropipettes filled with $4 \mathrm{~m}$ potassium acetate plus $0.01 \mathrm{M} \mathrm{KCl}$. Electrode resistance was approximately $80-100 \mathrm{M} \Omega$. Cell stimulation was carried out using both intracellular current injection $(100 \mathrm{msec}$ pulses of $0.5 \mathrm{nA}$ depolarizing current through the recording electrode via a bridge circuit) and extracellular stimulation (bipolar tungsten electrodes) of orthodromic pathways in stratum radiatum or "antidromic" pathways in the alveus. Cellular input resistance $\left(R_{\mathrm{in}}\right)$ was estimated by injecting hyperpolarizing current pulses $(0.5 \mathrm{nA}, 100 \mathrm{msec})$ into the cell and measuring the resulting steady-state voltage deflection from resting membrane potential (RMP). The membrane time constant $\left(T_{m}\right)$ was estimated from such a charging curve as the time required to reach $63 \%$ $\left(1-e^{-1}\right)$ of the maximum voltage deflection; exponential peeling to adjust for an initial rapid time constant was not performed. Membrane potential was altered by injection of either depolarizing or hyperpolarizing DC current into the cell through the recording electrode; bridge balance was continuously monitored and adjusted as necessary during this procedure. Data were displayed on an oscilloscope and stored on magnetic tape for later analysis with a computer.

Intracellular recordings were obtained from $\mathrm{CA} 1$ pyramidal cells by lowering the recording electrode in stratum pyramidale. "Basket cell" interneurons (Schwartzkroin and Mathers, 1978; Knowles and Schwartzkroin, 1981) were recorded from by positioning the electrode at the stratum pyramidale/oriens border. When the recording electrode was placed at the $\mathrm{O} / \mathrm{A}$ border, intracellular recordings could be obtained from "oriens/alveus interneurons." Intrinsic and synaptic properties of these interneuron types were evaluated electrophysiologically and compared with those of CAl pyramidal neurons.

For paired intracellular recordings, an electrode was first lowered at the $\mathrm{O} / \mathrm{A}$ border. After successful penetration of an $\mathrm{O} / \mathrm{A}$ interneuron, a stabilizing hyperpolarizing current was injected into the cell while an attempt was made to penetrate a pyramidal or nonpyramidal cell with a second electrode. When a second successful penetration was obtained, depolarizing current pulses $(100 \mathrm{msec}, 0.5 \mathrm{nA}, 0.5 \mathrm{~Hz})$ were applied to 1 cell, and correlated membrane voltage changes were sought in the other cell. The procedure was then repeated, but in reverse, to examine interactions in the opposite direction.

In a number of pairs, the unitary postsynaptic potentials (PSP) evoked in $\mathrm{O} / \mathrm{A}$ interneurons were measured for peak amplitude and latency to peak. The peak amplitude was measured as the voltage difference in the $\mathrm{O} / \mathrm{A}$ interneuron between baseline just prior to the $\mathrm{CA} 1$ pyramidal cell action potential and the maximum voltage shortly following the coupling artifact (see Fig. 3). The latency to peak was defined as the time difference between the peak of the $\mathrm{C} \Lambda \mathrm{l}$ pyramidal cell action potential and the peak amplitude of the PSP in the O/A interneuron. The $\mathrm{O} / \mathrm{A}$ action potential latency was defined as the time difference between the peak of the CA1 action potential and the peak of the $\mathrm{O} / \mathrm{A}$ interneuron action potential. PSPs in interneurons were considered spontaneous if the onset of the PSP preceded the pyramidal cell action potential. In our measurements of PSPs amplitude we did not use averaging techniques to reduce the noise level of the recording system. The PSPs were clearly of large enough amplitude for us to resolve them by visual inspection of the voltage trace. Failures were counted when, under visual inspection, the voltage trace did not differ from background noise level (approximately $+0.5 \mathrm{mV}$ )

Lucifer yellow intracellular injections. In many cases, a qualitative morphological analysis of the intracellularly recorded $\mathrm{O} / \mathrm{A}$ interneuron was attempted. In such experiments, the recording electrode was filled with 4\% LY (Lucifer yellow CH; Sigma Chemical Co.) in $1 \mathrm{M} \mathrm{LiCl}$ (Stewart, 1978, 1981). An O/A interneuron was impaled and analyzed electrophysiologically; then 0.5-2.0 nA hyperpolarizing DC current was applied to the recording electrode via the bridge circuit in order to eject the LY. An ejection time of 2-3 min was usually sufficient to label the neuron, with 5-8 min being optimal. All electrophysiological data were collected prior to filling the cell with LY in order to avoid the complications arising from intracellular chloride accumulation or from LY effects on cell viability.

The slice containing an LY-filled interneuron was allowed to lay undisturbed for anproximately $10 \mathrm{~min}$ after withdrawal of the recording electrode. The slice was then transferred gently to a plastic petri dish, sandwiched between 2 pieces of filter paper, and covered with fixative (either $4 \%$ formalin in PBS, $\mathrm{pH} 7.4$, or $3 \%$ paraformaldehyde lysine periodate (PLP) (Kunkel, et al., 1986). The slice was fixed for 4-16 hr at $4^{\circ} \mathrm{C}$, and was then transferred into PBS containing $30 \%$ sucrose. After 3-4 hr, frozen sections $40-60 \mu \mathrm{m}$ were cut and mounted in buffer. The LY-filled interneuron was examined under a Leitz Dialux 20 epifluorescence microscope.

Intracellular $H R P$ injections. Electrodes were filled with 4\% HRP (Sigma Type VI), dissolved in $0.25 \mathrm{M} \mathrm{KCl}$ and $0.05 \mathrm{M}$ Tris $\mathrm{HCl}(\mathrm{pH}$ 7.6), with Kodak Photo-flow added $(250 \mu \mathrm{l} / \mathrm{ml})$. HRP-filled microelectrode tips were broken back to yield final electrode resistances of 50 $150 \mathrm{M} \Omega$ in tissue. The electrode was then lowered at the O/A border. After a successful impalement of an $\mathrm{O} / \mathrm{A}$ interneuron, HRP was iontophoresed into the cell with positive current pulses (3-5 nA, $20 \mathrm{msec}$, $33 \mathrm{~Hz}$ ) for 2-10 min. Interneurons were injected with HRP within $4 \mathrm{hr}$ of slice preparation to ensure optimal tissue preservation for electron microscopy. Only a single $\mathrm{O} / \mathrm{A}$ interneuron was injected per slice. After HRP injection, the slice remained undisturbed in the chamber for an hour to allow diffusion and active transport of the HRP molecules within the cell. Slices with an HRP-filled neuron were then transferred to a petri dish and fixed between 2 pieces of filter paper as described below.

HRP light and electron microscopy. Slices containing HRP-filled neurons were immersion fixed in $2 \%$ paraformaldehyde and $0.5 \%$ glutaraldehyde in $0.1 \mathrm{M}$ sodium cacodylate buffer $(\mathrm{pH} 7.4)$ for $16-24 \mathrm{hr}$ at $5^{\circ} \mathrm{C}$. Slices were sunk in $0.1 \mathrm{~m}$ sodium cacodylate containing $30 \%$ sucrose (minimum $2 \mathrm{hr}$ ). Frozen sections $60-80 \mu \mathrm{m}$ were cut and rinsed in 0.1 $\mathrm{M}$ sodium cacodylate ( $\mathrm{pH} 7.6$ ). The sections were then rinsed in $0.1 \mathrm{M}$ Tris- $\mathrm{HCl}$ buffer ( $\mathrm{pH} 7.6$ ), followed by a pretreatment in a $0.05 \%$ solution of $\mathrm{CoCl}_{2}$ in $0.1 \mathrm{M}$ Tris- $\mathrm{HCl}(\mathrm{pH} 7.6$ ) for $20 \mathrm{~min}$. After sequential buffer rinses in $0.1 \mathrm{M}$ Tris- $\mathrm{HCl}$ and $0.1 \mathrm{M}$ Sorenson's phosphate $(\mathrm{pH} 7.6)$, the sections were preincubated in a freshly prepared solution of $0.05 \% 33^{\prime}$ diaminobenzidine tetrahydrochloride (DAB; Sigma) in $0.1 \mathrm{~m}$ phosphate buffer ( $\mathrm{pH} \mathrm{7.6)}$ for 10 min at room temperature. Sections were then placed in a fresh $\mathrm{DAB}$ solution containing $0.03 \% \mathrm{H}_{2} \mathrm{O}_{2}$ and incubated for an additional $30 \mathrm{~min}$. After thorough rinsing in buffer, sections were wet-mounted in buffer and photographed using bright-field illumination on a Leitz Dialux 20 photomicroscope. When HRP-filled processes were 
Table 1. Electrophysiological properties of $\mathrm{O} / \mathrm{A}$ interneurons, basket cell interneurons, and randomly selected CA1 pyramidal neurons

\begin{tabular}{|c|c|c|c|}
\hline Characteristic & $\mathrm{O} / \mathrm{A}$ interneuron & $\begin{array}{l}\text { Stratum pyramidale } \\
\text { interneuron }\end{array}$ & $\begin{array}{l}\text { CA1 pyramidal } \\
\text { neuron }\end{array}$ \\
\hline Membrane potential (mV) & $-51 \pm 3$ & $-55 \pm 1$ & $-58 \pm 2$ \\
\hline Input resistance $(\mathrm{M} \Omega)$ & $42 \pm 4$ & $40 \pm 9$ & $31 \pm 2$ \\
\hline Time constant (msec) & $5.6 \pm 0.4(18)$ & $5.8 \pm 0.7$ & $10.6 \pm 0.8$ \\
\hline Spontaneous activity $(\mathrm{Hz})$ & $27 \pm 5$ & $4 \pm 2$ & $3 \pm 2$ \\
\hline Spike amplitude (mV) & $43 \pm 2 \quad(41)$ & $48 \pm 5$ & $62 \pm 3$ \\
\hline Spike duration (msec) & $1.1 \pm 0.1(32)$ & $0.78 \pm 0.06(7)$ & $1.73 \pm 0.12(15)$ \\
\hline Spike AHP $(\mathrm{mV})$ & $-8.1 \pm 0.9(32)$ & $-8.7 \pm 2.6$ & $0^{a}$ \\
\hline Spikes/current burst $(n)$ & $12 \pm 1$ & $12 \pm 1$ & $7 \pm 1$ \\
\hline Burst AHP & $6 / 27$ cells & $1 / 6$ cells & $9 / 15$ cells \\
\hline \multicolumn{4}{|l|}{ Alvear stimulation } \\
\hline Spike & $9 / 20$ cells & $3 / 7$ cells & $13 / 15$ cells \\
\hline Burst & $11 / 20$ cells & $1 / 7$ cells & $0 / 15$ cclls \\
\hline EPSP & $17 / 20$ cells & $3 / 4$ cells & $0 / 13$ cells \\
\hline LY-filled cells $(n)$ & $17 / 35$ cells & $1 / 7$ cells & $4 / 15$ cells \\
\hline
\end{tabular}

These neuronal types were characterized with intracellular recordings, and the following properties were compared (mean $\pm \mathrm{SE}$ ): resting membrane potential, input resistance, membrane time constant, spontaneous firing rate, action potential amplitude, action potential duration, amplitude of afterhyperpolarization (AHP) following a single action potential, number of action potentials evoked by a depolarizing current pulse $(0.5 \mathrm{nA}, 100 \mathrm{msec})$, presence or absence of an AHP following such a current-evoked train of action potentials, and response to stimulation of the alveus (single spike or burst, and the presence or absence of an underlying EPSP). A number of these neurons were subsequently filled with LY for morphological analysis.

a Pyramidal cells show a depolarizing afterpotential (DAP) at the postspike latency of the interneuron AHP.

found, adjacent serial sections were also examined in attempts to follow processes through the tissue.

The HRP-filled neurons were easily recognized and small blocks (approx. $0.75 \times 2 \mathrm{~mm}$ ) containing filled neurons were cut and processed for electron microscopy. Blocks were osmicated, rinsed, dehydrated, and embedded in Medcast between Teflon-coated coverslips or plastic slides. Serial sections (silver to yellow interference color) were cut, stained with uranyl acetate and lead citrate, and examined on a Philips 410 EM. When HRP-filled processes were found, adjacent serial sections were also examined in attempts to follow the contact site serially.

\section{Results}

\section{Intracellular response characterization}

Successful impalements were obtained in 41 neurons (in 34 slices from 30 guinea pigs) located at the $\mathrm{O} / \mathrm{A}$ border in area CA1. Recording electrodes were filled either with $4 \mathrm{M}$ potassium acetate plus $0.01 \mathrm{M} \mathrm{KCl}$ or $4 \% \mathrm{LY}$ in $1 \mathrm{M} \mathrm{LiCl}$. These neurons were charactcrized clcctrophysiologically as nonpyramidal (Fig. 1; Table 1) and will henceforth be referred to as "oriens/alveus interneurons." The average RMP $( \pm S E)$ of these interneurons was relatively low $(-51 \pm 3 \mathrm{mV})$. It is difficult to say whether this low RMP is a true characteristic of this cell type or whether it is simply due to relatively poor impalements. On the one hand, these cells were extremely difficult to find, impale, and hold, primarily because of their low packing density as compared to the somata of CA1 pyramidal neurons in stratum pyramidale. On the other hand, the relatively high $R_{\text {in }}$ values (mean, $42 \pm 4 \mathrm{M} \Omega$ ) suggest that the impaled cells were healthy. In these alveus/oriens cell impalements, there was no correlation between RMP and $R_{\text {in }}$ values $(r=0.07)$. In the paired recordings experiments (see below) in which stable impalements were maintained for longer periods, the $\mathrm{O} / \mathrm{A}$ interneurons had an average RMP of $-57 \mathrm{mV}$, and an average spike amplitude of $58 \mathrm{mV}$, probably reflecting "healthier" impalements.

The A/O cells had short time constants (5.6 $\pm 0.4 \mathrm{msec})$, a high rate of spontaneous activity $(27 \perp 5 \mathrm{IIz})$, a relatively low spike amplitude $(43 \pm 2 \mathrm{mV})$, and a short spike duration ( $1.1 \pm$ $0.1 \mathrm{msec}$ ). Perhaps the most conspicuous feature of these interneurons was the presence of a very pronounced brief afterhyperpolarization (AHP; mean amplitude, $-8.1 \pm 0.9 \mathrm{mV}$ ) following a single spike. These neurons responded to a depolarizing current pulse $(0.5 \mathrm{nA}, 100 \mathrm{msec})$ with a nondecrementing train of $12 \pm 1$ action potentials. An AHP followed this current-evoked firing in only 6/27 cells (see Fig. 9, for example). Stimulation of the alveus (antidromic for CA1 pyramidal neurons) evoked a single spike in $9 / 20$ interneurons and a burst in 11/20 interneurons; an underlying EPSP could be seen in 17 of these 20 interneurons (Fig. 1).

Occasionally, a pyramidal cell dendrite was impaled in the O/A border. Dendritic recordings could be distinguished easily from interneuron recordings. Pyramidal dendritic recordings showed typical fractionated burst response to depolarizing current pulses (Wong et al., 1979), whereas interneuron recordings displayed sustained action potential firing with such depolarizing pulses. Also, pyramidal cells responded to alvear stimulation with a large IPSP and at higher stimulation intensity with an antidromic spike. In contrast, $\mathrm{O} / \mathrm{A}$ interneurons responded with a large EPSP and a burst of spikes. This ability to differentiate between neuronal types was also verified by LY injection.

Intracellular recordings were also obtained from "basket cell" interneurons located at the stratum pyramidale/oriens border $(n=7)$. These neurons were characterized as nonpyramidal on the basis of electrophysiological data (Table 1). Basket cell interneurons differed only slightly from $\mathrm{O} / \mathrm{A}$ interneurons. First, basket cells fired relatively slowly at rest $(4 \pm 2 \mathrm{~Hz})$ compared to alveus/oriens neurons. Second, basket cells rarely responded to stimulation of the alveus with a burst of action potentials. When a burst response was noted in basket cells, it was unlike that seen in an O/A interneuron; a burst in the basket cell did 
Figure 1. Electrophysiological characterization of $\mathrm{O} / \mathrm{A}$ interneurons. This $\mathrm{O} / \mathrm{A}$ interneuron fired spontaneously at a rate of approximately $20 \mathrm{~Hz}$. Note the pronounced AHP following a single spike. A depolarizing current pulse $(0.5$ $\mathrm{nA}, 100 \mathrm{msec}$ duration, onset and offset marked by dots) evoked a train of action potentials. This current-evoked train was not followed by an AHP. Stimulation of the alveus (arrow) elicited a pronounced burst of action potentials riding on a depolarizing envelope. Note that the cell fired an initial full action potential, followed by a period of inactivation, and then resumed firing; this pattern of stimulus-evoked burst was characteristic of this interneuron type. An underlying EPSP could be seen when the cell was hyperpolarized to block spike discharge. RMP $-62 \mathrm{mV}$. This cell was filled subsequently with LY for morphological characterization (Fig. 2). spontaneous activity
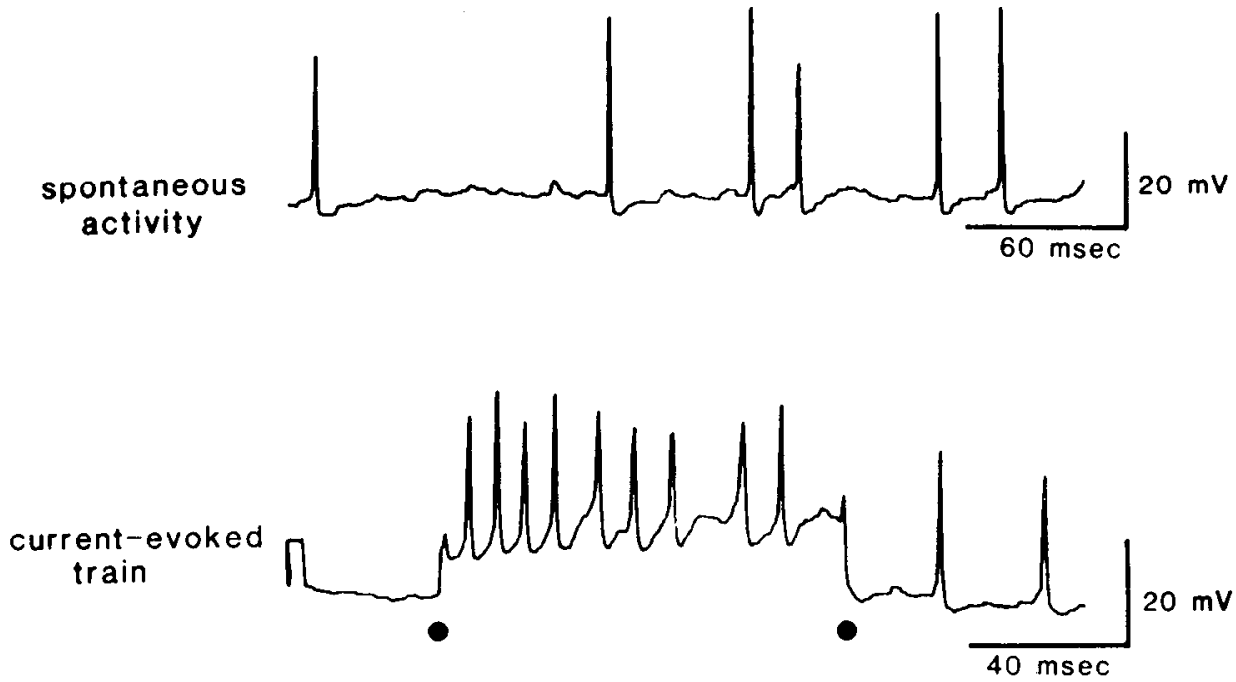

alvear stim.

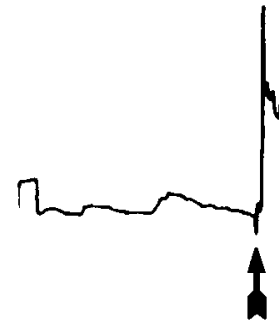

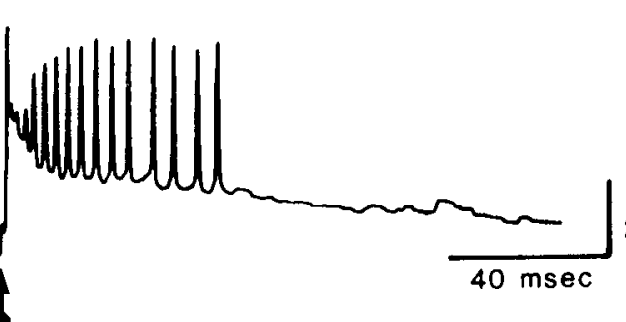
$20 \mathrm{mV}$

alvear stim. (hyperpolarized)

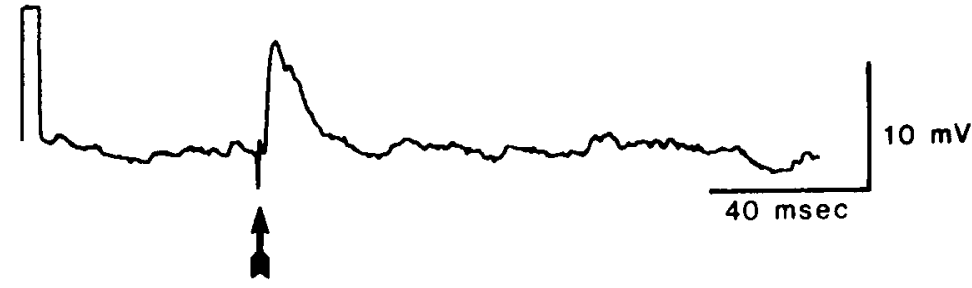

not show the marked spike inactivation (spike amplitude decrement) at the peak of a depolarization typical of the $\mathrm{O} / \mathrm{A}$ cell burst (Fig. 1).

A number of $\mathrm{O} / \mathrm{A}$ interneurons were characterized morphologically with LY injection following the collection of electrophysiological data (17/35 cells). These morphological studies confirmed the nonpyramidal nature of $\mathrm{O} / \mathrm{A}$ interneurons (Fig. 2). The majority of LY-filled interneurons were bi- or multipolar cells, 20-30 $\mu \mathrm{m}$ in diameter, with their soma located at the O/A border. Most cellular processes appeared to course parallel to the alveus. In many cells, 1 or 2 large processes, probably dendrites, followed along the alveus for a short distance, then turned perpendicularly and ascended through stratum pyramidale and stratum radiatum. An axon could occasionally be followed from the $\mathrm{O} / \mathrm{A}$ border into stratum pyramidale, where it branched profusely (arrow, Fig. 2).

\section{Synaptic interactions}

Tests for synaptic interactions were performed in 53 pairs of cells.

\section{O/A interneuron-CAI pyramidal cell pairs}

Forty-five $\mathrm{O} / \mathrm{A}$ interneuron-CA1 pyramidal cell pairs were tested with depolarizing current pulses in pyramidal cells. In 29 of the 45 pairs $(64 \%)$, excitatory interactions from pyramidal cells to $\mathrm{O} / \mathrm{A}$ interneurons were found. Excitatory postsynaptic potentials (EPSPs) in the O/A interncurons closcly followed the firing of action potentials in the CA I pyramidal cell (Fig. 3). In 10 of the 29 pairs, the EPSPs were large enough to reach threshold and fire action potentials in $\mathrm{O} / \mathrm{A}$ interneurons (Fig. 3). These pyramidal cell-evoked EPSPs in $\mathrm{O} / \mathrm{A}$ interneurons were characterized in greater detail in 27 pairs (Table 2). In 22 of the pairs, EPSPs were not always detected after a CA1 pyramidal spike. Overall, the probability of an EPSP failure was 0.34 (292/ 855 ). Thus, the probability of eliciting an EPSP (or an EPSPspike sequence) was 0.66 . Overall, the mean peak amplitude $( \pm \mathrm{SD}$ ) of these EPSPs was $2.16 \pm 0.95 \mathrm{mV}$, and the mean latency to the EPSP peak was $3.83 \pm 0.92 \mathrm{msec}$. The mean latency to the peak of elicited action potentials was $3.79 \pm 1.24 \mathrm{msec}$. That the $\mathrm{O} / \mathrm{A}$ interneuron received strong excitatory input from 

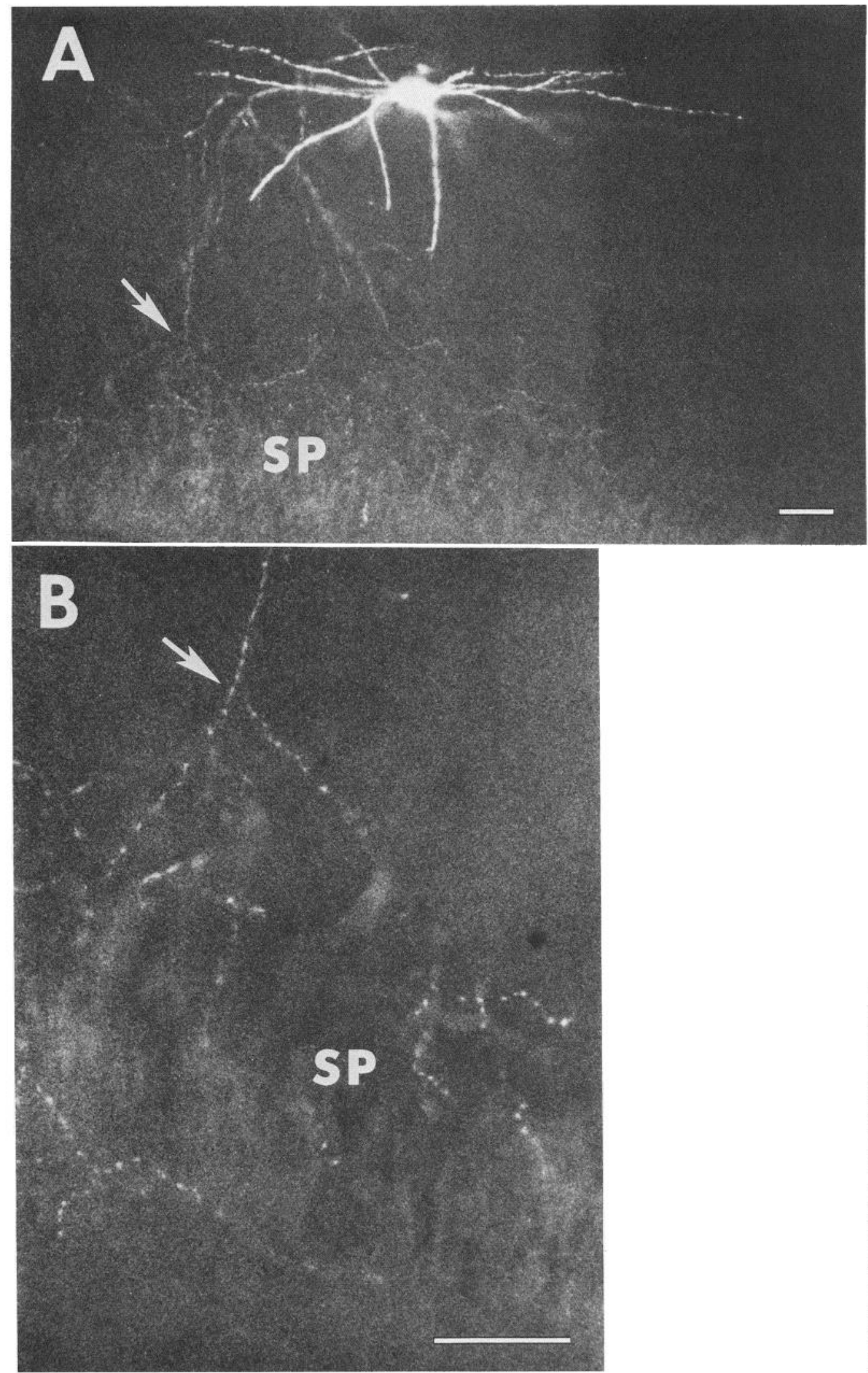

Figure 2. LY-filled O/A interneuron. $A$, Interneuron located at the stratum oriens/alveus border in area CAl was filled with the fluorescent dye. Most cellular processes are oriented parallel to the alveus. A few large, prominent processes (dendrites) ascend through stratum pyramidale $(S P)$ towards stratum lacunosum-moleculare. One can see the beginnings of 3 such processes, which were cut by the plane of sectioning, in this photograph. $B$, Thin axon arises from the cell body, travels parallel to the alveus for a short distance, turns toward pyramidale, and then branches (arrow) and ramifies extensively throughout stratum pyramidale. This interneuron was characterized electrophysiologically (Fig. 1). Calibration bars, $50 \mu \mathrm{m}$.

pyramidal cells was also evident from activity evoked in $\mathrm{O} / \mathrm{A}$ cells by moving a recording micropipette through the stratum pyramidale and trying to impale CA1 pyramidal cells. When the electrode was stationary, only occasional spontaneous EPSPs were seen in $\mathrm{O} / \mathrm{A}$ interneurons. However, when the pyramidale electrode was moved, and dendrites and somas were impaled and injured (i.e., depolarized), spontaneous EPSPs in the O/A cell occurred at an enhanced rate (for about a second). 
A

CA1 pyramidal cell

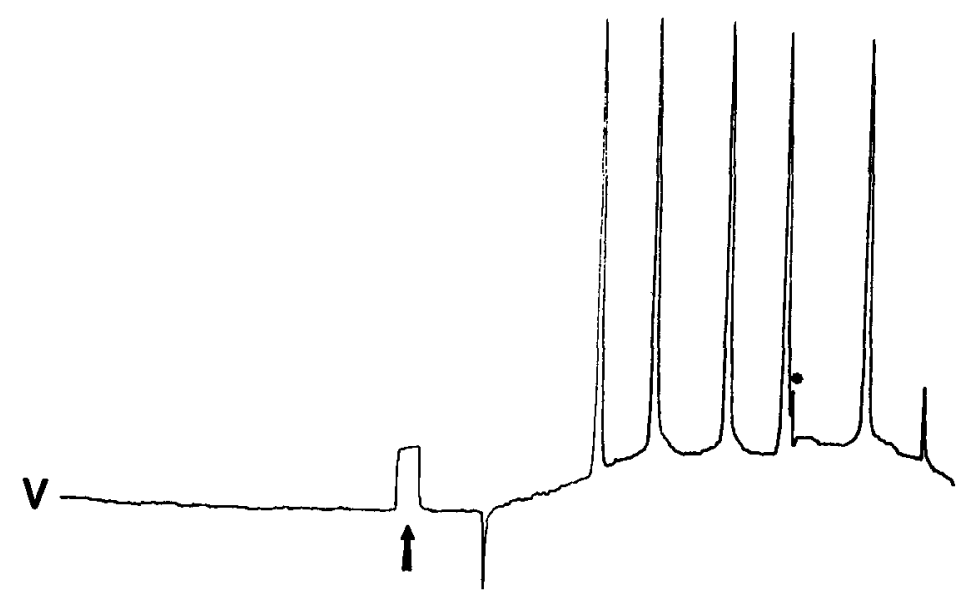

$10 \mathrm{~ms}$

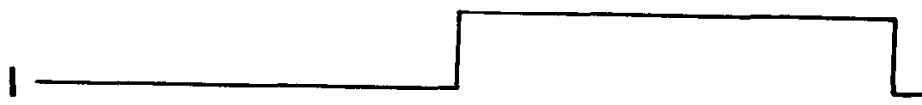

I

o/a interneuron

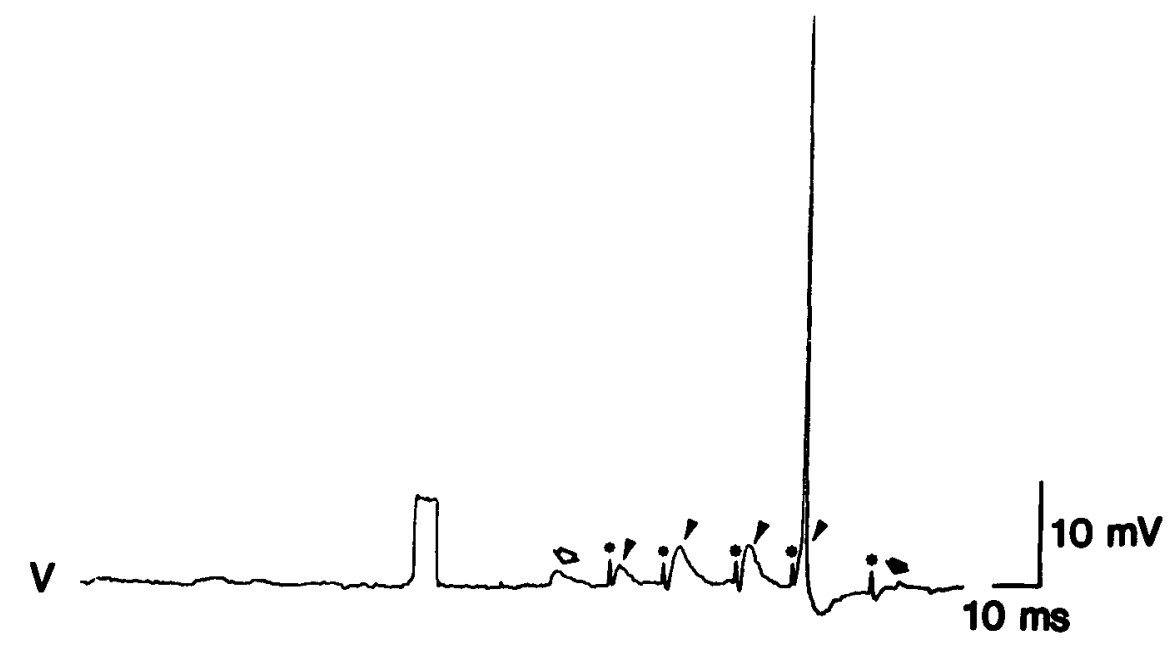

B

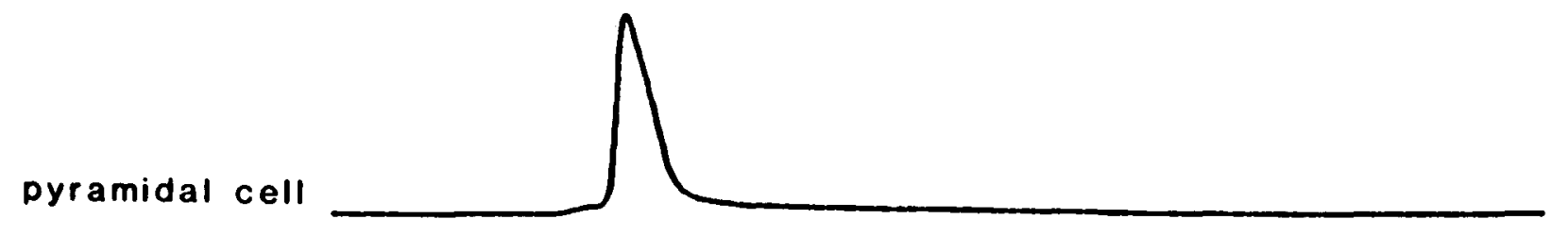

interneuron

$\Lambda$

$5 \mathrm{msec}$

Figure 3. Excitatory synaptic interactions from a CA1 pyramidal cell to an $\mathrm{O} / \mathrm{A}$ interneuron. $A$, Depolarizing current pulse (middle trace) in the CA1 pyramidal cell evoked 5 action potentials in the CA1 cell (top trace). In the O/A interneuron (bottom trace), EPSPs (thin arrowheads) were produced following the first 4 action potentials. In the case of the fourth EPSP, it reached threshold and triggered action potential. The fifth CA1 action potential failed to evoke a response in the interneuron (thick arrowhead). A spontaneous EPSP (open arrowhead) preceded this evoked activity. These spontaneous events seemed to occur randomly and were not stimulus dependent. Small dots indicate capacitative coupling artifacts. Arrow points to $5 \mathrm{msec}, 10 \mathrm{mV}$ calibration mark. O/A interneuron RMP, $-6 \mathrm{C} \mathrm{mV}$; CAl pyramidal cell RMP, $-58 \mathrm{mV}$. B, In a different pair of $\mathrm{O} / \mathrm{A}$ interneuron and $\mathrm{CA} 1$ pyramidal cell, a single spontaneous action potential in the pyramidal cell evoked an EPSP-like event in the interneuron. 
A1

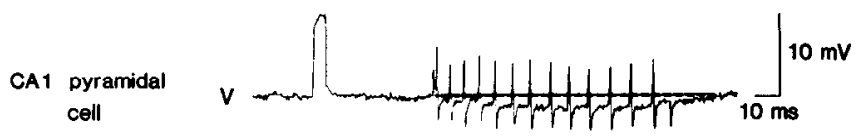

A2

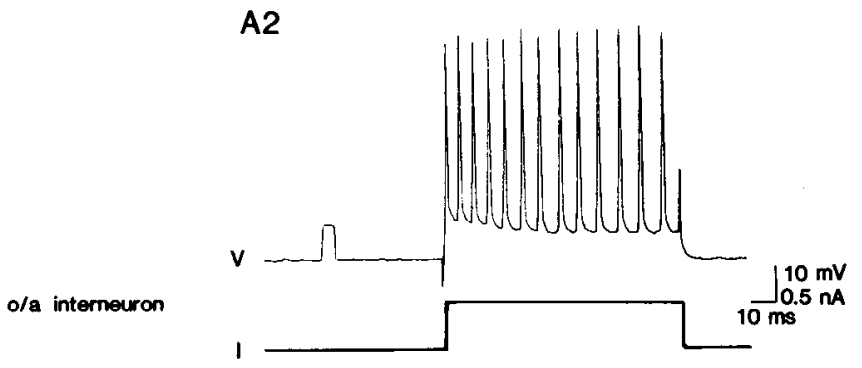

B1

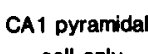

cell only

B2
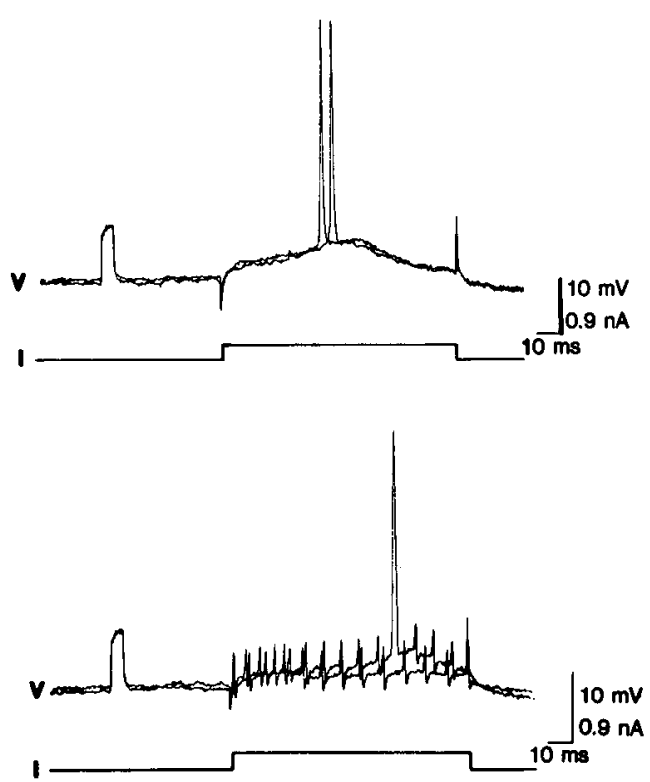

Figure 4. Inhibitory synaptic interactions from an $\mathrm{O} / \mathrm{A}$ interneuron to a $\mathrm{CA} 1$ pyramidal cell. $A$, Depolarizing current pulse in the $\mathrm{O} / \mathrm{A}$ interneuron evokes a burst of action potentials in the interneuron $(A 2)$. During the $\mathrm{O} / \mathrm{A}$ burst, a hyperpolarization is produced in the CA1 pyramidal cell $(A 1)$. Following the burst, the membrane returns to preburst level (dotted line in $A 1$ ). $B$, Intracellular injection of a low-amplitude current pulse ( $B 1$, bottom trace) consistently triggered an action potential in the CA1 pyramidal cell $(B 1$, top trace; same cell as in $A 1)$. When that same depolarizing current pulse $(B 2$, bottom trace) was paired with activation of the $\mathrm{O} / \mathrm{A}$ interneuron (as in $A 2)$, the pyramidal cell discharge was either blocked or delayed $(B 2$, top trace). The small spikelike events in $A I$ and $B 2$ are capacitative coupling artifacts arising from action potentials in the interneuron. $\mathrm{O} / \mathrm{A}$ interneuron $\mathrm{RMP},-75 \mathrm{mV}$.

In $42 \mathrm{O} / \mathrm{A}$ interneuron-CA1 pyramidal cell pairs, depolarizing pulses were injected into $\mathrm{O} / \mathrm{A}$ interneurons. These depolarizations produced nonaccommodating bursts of action potentials in the interneurons (Figs. $4 A, 5 A$ ). In $3 \mathrm{CAl}$ pyramidal cells $(7 \%)$, small IPSPs were observed during burst firing in O/A interneurons (Fig. 4). These IPSPs were of low amplitude and lasted the duration of the burst. They were sufficient, however, to inhibit or delay CAl action potentials normally evoked by rheobasic current injection into the pyramidal cell (cf. Fig. 4, $B 1$ and $B 2$ ).

In $1 \mathrm{O} / \mathrm{A}$ interneuron-CA1 pyramidal pair, reciprocal interactions were found. Depolarization-induced firing of the pyramidal cell resulted in EPSPs in the O/A interneuron (Fig. $5 B$ ). Depolarization-induced firing of the $\mathrm{O} / \mathrm{A}$ interneuron produced a low-amplitude, slow IPSP in the pyramidal cell (Fig. $5 A$ ) and inhibited its discharge in response to rheobasic current injection (not shown).

Feedforward activation of the O/A interneuron-that is, direct afferent drive, without prior pyramidal cell excitation - was also observed. The response of an $\mathrm{O} / \mathrm{A}$ interneuron-pyramidal cell pair to stimulation of stratum radiatum is illustrated in Figure 6. Stimulation produced an EPSP-action potential-IPSP sequence in the $\mathrm{C} \Lambda 1$ pyramidal cell (Fig. $6 B$ ). In the $\mathrm{O} / \mathrm{A}$ interneuron, a much larger EPSP was produced, and 7 action potentials were evoked with 1 nearly completely inactivated. The first 2 action potentials in the $\mathrm{O} / \mathrm{A}$ interneuron preceded the action potential in the pyramidal cell; in this pair, the first $\mathrm{O} / \mathrm{A}$ interneuron spike preceded the CAl action potential by
2.0 msec. Further, stimulus intensities consistently below those required to activate pyramidal cells were sufficient to trigger action potentials in the $\mathrm{O} / \mathrm{A}$ interneurons (Fig. $6 A$ ).

\section{O/A interneuron-nonpyramidal cell pairs}

Synaptic interactions between $\mathrm{O} / \mathrm{A}$ interneurons and nonpyramidal cclls (Schwartzkroin and Mathers, 1978; Knowles and Schwartzkroin, 1981) in stratum pyramidale were examined in 7 pairs of cells. When depolarizing current pulses were applied to pyramidale interneurons to trigger action potential trains, EPSPs were observed in 2 O/A interneurons (29\%) (Fig. 7)however, see Discussion. No effects were found in the other pairs. Even in the "positive" pairs, EPSPs were not always present in the $\mathrm{O} / \mathrm{A}$ interneuron following a spike in the pyramidal interneuron (Table 2). The probability of failure to detect an EPSP was $0.65(141 / 217)$. The EPSPs that were triggered were rarely large enough to trigger action potentials in $\mathrm{O} / \mathrm{A}$ interneurons. Their mean peak amplitude was $1.70 \pm 0.28 \mathrm{mV}$, with a mean latency of $3.48 \pm 0.05 \mathrm{msec}$.

In 1 of the $6 \mathrm{O} / \mathrm{A}$ interneuron-pyramidal interneuron pairs tested, an inhibitory connection was found. Stimulation of the $\mathrm{O} / \mathrm{A}$ interneuron produced a large IPSP in the pyramidal interneuron (Fig. 8). The duration of the IPSP was variable, often lasting much longer than the duration of the $\mathrm{O} / \mathrm{A}$ burst.

\section{Ultrastructure of HRP-filled $\mathrm{O} / \mathrm{A}$ interneurons}

Four HRP-filled O/A interneurons were successfully recovered and examined ultrastructurally. These interneurons were mor- 
A1

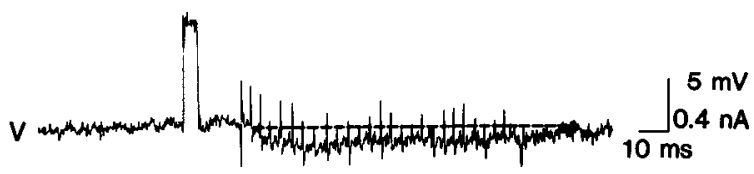

CA1 pyramidal cell$$
\text { I }
$$

\section{A2}

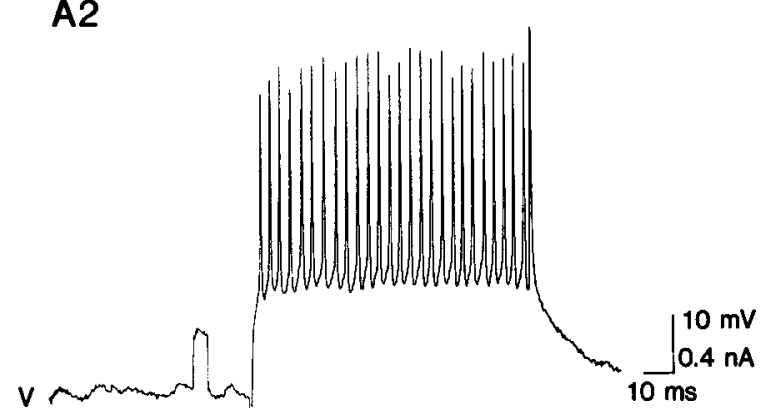

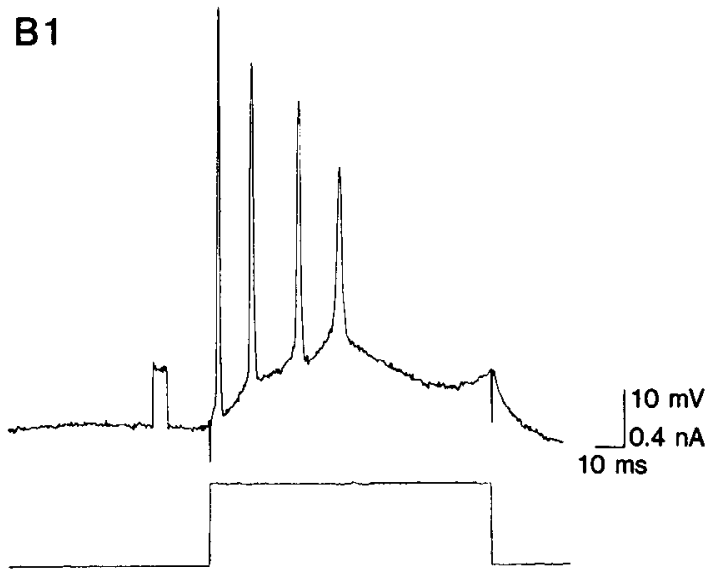

B2

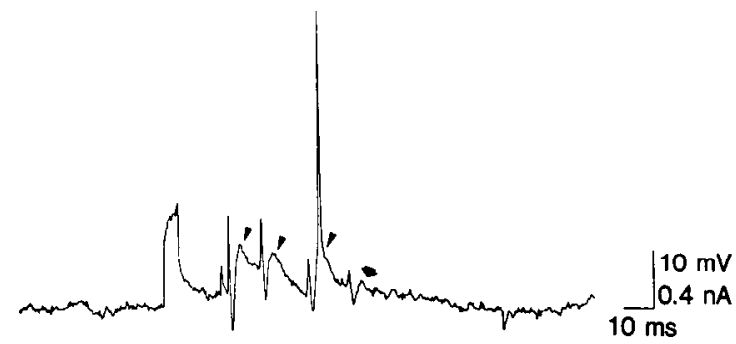

o/a interneuron

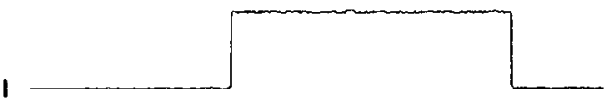

Figure 5. Reciprocal interactions between an $\mathrm{O} / \mathrm{A}$ interneuron and a CA1 pyramidal cell. $A$, Depolarizing current $(A 2$, bottom trace $)$ injected into the interneuron evoked a train of action potentials in it $(A 2$, top trace) and a small hyperpolarization in the pyramidal cell ( $A 1$, top trace). The membrane returned to prestimulation level (dotted line) after the burst. $B$, Depolarizing current $(B 1$, bottom trace) evoked 4 action potentials in the pyramidal cell $(B 1$, top trace). The first 3 action potentials elicit EPSPs in the interneuron (thin arrowhead in $B 2$, top trace). The third EPSP is large enough to trigger an action potential. The fourth CA1 action potential fails to evoke an EPSP in the interneuron (thick arrowhead, B2, top trace). Pyramidal cell RMP, $-57 \mathrm{mV}$; O/A interneuron RMP, $-48 \mathrm{mV}$.

phologically similar to those identified by LY injection (Fig. 2). HRP-filled dendritic processes were oriented parallel to the alveus at the $\mathrm{O} / \mathrm{A}$ border. The axon was observed to leave the soma, travel parallel to the alveus, and then turn perpendicularly and ascend towards the stratum pyramidale. Axonal processes were varicose in appearance and were found primarily in strata oriens and pyramidale. The intracellular response of an O/A interneuron to a depolarizing current pulse, prior to HRP injection, is illustrated in Figure $9 A$, along with its HRP-filled synaptic contacts. Synaptic contacts, both en passant and ter- minaux, were observed on pyramidal cell somata and dendrites. The synaptic contacts appeared as Type II symmetric synaptic contacts (Whittaker and Gray, 1962; Schwartzkroin and Kunkel, 1985) with (1) an accumulation of presynaptic vesicles near the contact site, (2) close apposition of the pre- and postsynaptic membranes with the presence of cleft material, and (3) a thin, even postsynaptic membrane specialization (in contrast to the thick postsynaptic specialization of type I contacts) (Fig. 9, B, $D$, and $F$ ). Apparent symmetric synaptic contacts could be seen on individual pyramidal cell somata (Fig. $9 B$ ) and dendrites

Table 2. Summary table of characteristics of depolarizing postsynaptic responses in $\mathrm{O} / \mathrm{A}$ interneurons following presynaptic stimulation of $\mathrm{CA1}$ pyramidal cells or CA1 interneurons in stratum pyramidale

\begin{tabular}{|c|c|c|c|c|c|c|c|}
\hline & \multirow{4}{*}{$\begin{array}{l}\text { Pyramidal } \\
\text { neuron: } \\
\text { spikes } \\
\text { evoked } \\
(n)\end{array}$} & \multicolumn{6}{|c|}{$\mathrm{O} / \mathrm{A}$ interneuron } \\
\hline & & \multirow{2}{*}{\multicolumn{2}{|c|}{ Action potentials }} & \multicolumn{4}{|c|}{ EPSP } \\
\hline & & & & \multirow[b]{2}{*}{$n$} & \multirow{2}{*}{$\begin{array}{l}\text { EPSP } \\
\text { failures } \\
(n)\end{array}$} & \multirow[b]{2}{*}{$\begin{array}{l}\text { Mean }( \pm S D) \text { peak } \\
\text { amplitude }(\mathrm{mV})\end{array}$} & \multirow{2}{*}{$\begin{array}{l}\text { Mean }( \pm \text { SD) } \\
\text { peak latency } \\
(\mathrm{msec})\end{array}$} \\
\hline & & $n$ & $\begin{array}{l}\text { Mean }( \pm \mathrm{SD}) \\
\text { latency }(\mathrm{msec})\end{array}$ & & & & \\
\hline \multicolumn{8}{|l|}{ CAl pyramidal cells-O/A } \\
\hline interneuron (27 pairs) & 855 & 65 & $3.79 \pm 1.24$ & 498 & 292 & $2.16 \pm 0.95$ & $3.83 \pm 0.92$ \\
\hline \multicolumn{8}{|c|}{ Stratum pyramidalc interncurons- } \\
\hline $\mathrm{O} / \mathrm{A}$ interneurons (2 pairs) & 217 & 0 & - & 76 & 141 & $1.70 \pm 0.28$ & $3.48 \pm 0.05$ \\
\hline
\end{tabular}


A1

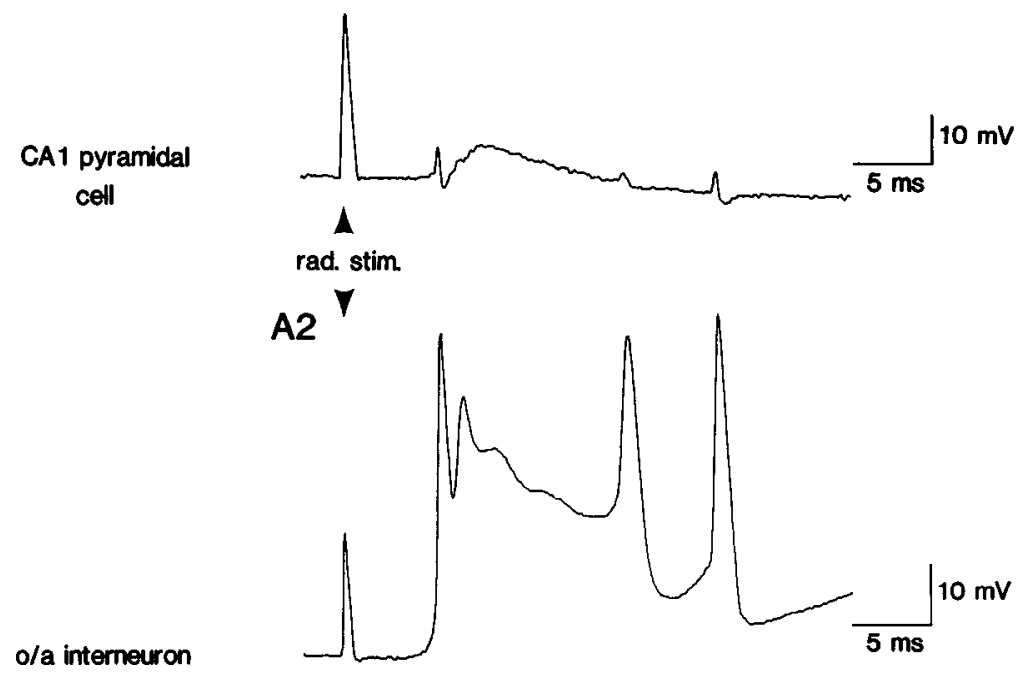

B1

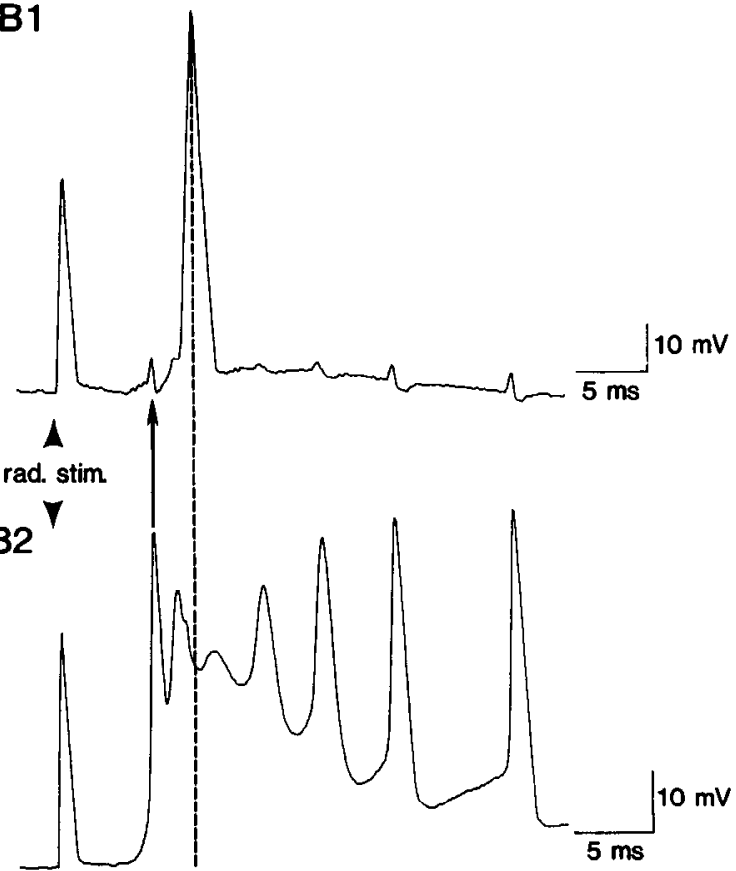

Figure 6. Feed forward excitation of an $\mathrm{O} / \mathrm{A}$ interneuron. Paired recordings from a CA1 pyramidal cell (top trace) and an $\mathrm{O} / \mathrm{A}$ interneuron (bottom trace). $A$, Stimulation of stratum radiatum $(50 \mu \mathrm{sec}, 100 \mu \mathrm{A}$, artifact in both traces indicated by arrowhead) evokes a small-amplitude EPSP in the pyramidal cell, followed by an IPSP $(A 1)$. No action potentials are evoked at this stimulation intensity. In the O/A interneuron $(A 2)$, the same stimulus evokes a large-amplitude, long-lasting EPSP that triggers 4 action potentials and is not followed by an IPSP. $B$, Stronger radiatum stimulation $(50 \mu \mathrm{sec}, 150 \mu \mathrm{A})$ evokes an EPSP and an action potential in the pyramidal cell $(B I)$. The same stimulus evokes a large EPSP and 7 action potentials in the interneuron (B2). The first spike in the $\mathrm{O} / \mathrm{A}$ interneuron (arrow pointing to coupling artifact in the other cell) precedes the pyramidal cell spike (dotted line) by $2.0 \mathrm{msec}$. The second spike in the interneuron also precedes the pyramidal cell spike. CAl pyramidal cell $\mathrm{RMP},-62 \mathrm{mV} ; \mathrm{O} / \mathrm{A}$ interneuron RMP, $-80 \mathrm{mV}$.

(Fig. 9, D, F). Each of these contacts displayed presynaptic vesicles (although partially obscured by the HRP dense reaction product), closely apposed pre- and postsynaptic membranes with cleft material, and a thin postsynaptic specialization (in contrast, see Fig. $9 D$, open arrow, for an example of a thick specialization). Other HRP-filled axons were nearly suggestive of synaptic contacts; for example, Figure $9 C$ shows a terminal in which the synaptic vesicles are more obscured and the postsynaptic specialization is not as prominent. HRP-filled interneuron terminal contacts onto dendrites were primarily on shafts of basal dendrites (Fig. $9 F$ ) but were occasionally seen on proximal apical dendrites in the stratum radiatum. HRP-filled axons also apposed pyramidal cell axon initial segments (Fig. 9E), possibly making synaptic contacts (presynaptic vesicles partly obscured). $\mathrm{O} / \mathrm{A}$ interneuron axons were seen apposed to other interneuron dendrites in the stratum oriens (Fig. 10, $A$ and $B$ ), suggesting synaptic contacts between interneurons.

\section{Discussion}

\section{Characterization of $\mathrm{O} / \mathrm{A}$ interneurons}

We were able to characterize, electrophysiologically and morphologically, a population of neurons located at the border between the stratum oriens and the alveus in the CA1 region of guinea pig hippocampus. These neurons were clearly nonpyramidal, and appeared to be a subpopulation of interneurons. The $\mathrm{O} / \mathrm{A}$ interneurons were electrophysiologically and morphologically different from pyramidal cells (Table 1) and showed no antidromic activation from alveus stimulation. They also differed from basket cells in terms of spontaneous firing rate and response to alvear stimulation (Table 1). Our electrophysiological data indicate that these $\mathrm{O} / \mathrm{A}$ interneurons are part of a discrete interneuronal pool that is different from the pyramidal basket cell interneurons.

It is more difficult, however, to classify $\mathrm{O} / \mathrm{A}$ interneurons as a distinct interneuronal type on the basis of our morphological data. While LY injection clearly showed these cells to be nonpyramidal, it was not always possible to predict cellular morphology from the electrophysiology. Most O/A interneurons had the following morphological characteristics: They were bipolar or multipolar cells; most cellular processes ran parallel to the alveus; and, most conspicuously, 1 or more very large processes ascended through the stratum pyramidale towards the stratum lacunosum-moleculare. However, not all $\mathrm{O} / \mathrm{A}$ interneurons displayed each of these characteristics. In addition, 1 neuron that was recorded from in the $\mathrm{O} / \mathrm{A}$ region, and which displayed typical interneuron-like physiology, was subsequently shown with $L Y$ injection to have a very nearly "pyramidal" shape.

\section{Local circuit interactions}

Using paired intracellular recordings, we observed excitatory synaptic interactions from CA1 pyramidal (and nonpyramidal cells?) on to $\mathrm{O} / \mathrm{A}$ interneurons. We also found inhibitory synaptic interactions from $\mathrm{O} / \mathrm{A}$ interneuron to $\mathrm{CA} 1$ pyramidal and nonpyramidal cells in a limited number of cases. These interactions are likely to be chemically mediated postsynaptic events and are similar to the interactions between pyramidal cells and basket cell interneurons (Knowles and Schwartzkroin, 1981). In response to intracellular stimulation of pyramidal cells, short- 


\section{str. pyramidale interneuron}

Figure 7. Excitatory interactions from a stratum pyramidale "interneuron" to an O/A interneuron. Depolarizing current pulse (middle trace) to the pyramidale cell evoked a burst of spikes (top trace). The second, fifth, and sixth spikes are followed in the O/A interneuron by small EPSPlike events (thin arrowheads). "Failures" (thick arrowhead) or spontaneous EPSPs (open arrowhead) are also visible in the O/A interneuron baseline. Stratum pyramidale interneuron RMP, $-65 \mathrm{mV}$; O/A interneuron RMP, $-48 \mathrm{mV}$.

latency unitary EPSPs were produced in O/A interneurons. In some cells, these EPSPs were of sufficient magnitude to trigger an action potential. The latency of these postsynaptic responses was typically monosynaptic, which can be accounted for by impulse conduction along the pyramidal cell axon, transmitter release and diffusion, and electrotonic spread of postsynaptic response. Our results indicate that the $\mathrm{O} / \mathrm{A}$ interneurons are strongly excited by CAl pyramidal cells.

Our measurements indicate that the mean unitary EPSP from a pyramidal cell to an $\mathrm{O} / \mathrm{A}$ interneuron is $2.16 \mathrm{mV}$. It should be pointed out that this measure is an approximation since the amplitude measurements were contaminated to some extent by the frequency facilitation that these EPSPs appear to display (see Fig. $3 A$, for example). However, as indicated in Figure $3 B$, in which the EPSPs shown were evoked at low frequency and therefore were not contaminated by frequency facilitation, these O/A interneuron unitary EPSPs are much larger than unitary EPSPs reported for other central synapses - approximately 200 $400 \mu \mathrm{V}$ (Redman and Wamsley, 1983). More detailed comparisons with other systems must await further studies of these interneuron EPSPs with averaging techniques and amplitude fluctuation analysis at frequencies producing no facilitation.

The EPSP responses in $\mathrm{O} / \mathrm{A}$ interneurons to stimulation of stratum pyramidale interneurons, seen in 2 pairs, were surprising. It is generally thought that the majority of stratum pyramidale interneurons are basket cells (Schwartzkroin and Mathers, 1978; Knowles and Schwartzkroin, 1981) and have an inhibitory function (using GABA as neurotransmitter). It is possible that the postsynaptic depolarizations we saw in the O/A interneurons were responses produced by GABA (Alger and Nicoll, 1979). However, it is more likely that the pyramidale interneurons stimulated in these 2 cases represent a different cell population. The stratum pyramidale "interneuron" of Figure 7 illustrates such a cell. Its spike width, firing rate, and AHP are characteristic of nonpyramidal neurons (Schwartzkroin and Mathers, 1978; Knowles and Schwartzkroin, 1981); however, the accommodation and spike inactivation during burst firing are typical of pyramidal cells. It is this "hybrid" type of cell (an interneuron?) that produced depolarizing responses in the $\mathrm{O} / \mathrm{A}$ interneuron.

Another striking feature of the $\mathrm{O} / \mathrm{A}$ interneurons is their powewrful excitatory response to stimulation of hippocampal CA1 afferents. Stimulation of the alveus or of stratum radiatum produced a large, slow EPSP that triggered many action potentials (see Figs. 1 and 6). Similar stimulation usually evokes an IPSP (alveus stimulation) or an EPSP-spike-IPSP sequence (radia- 


\section{str. pyramidale interneuron}
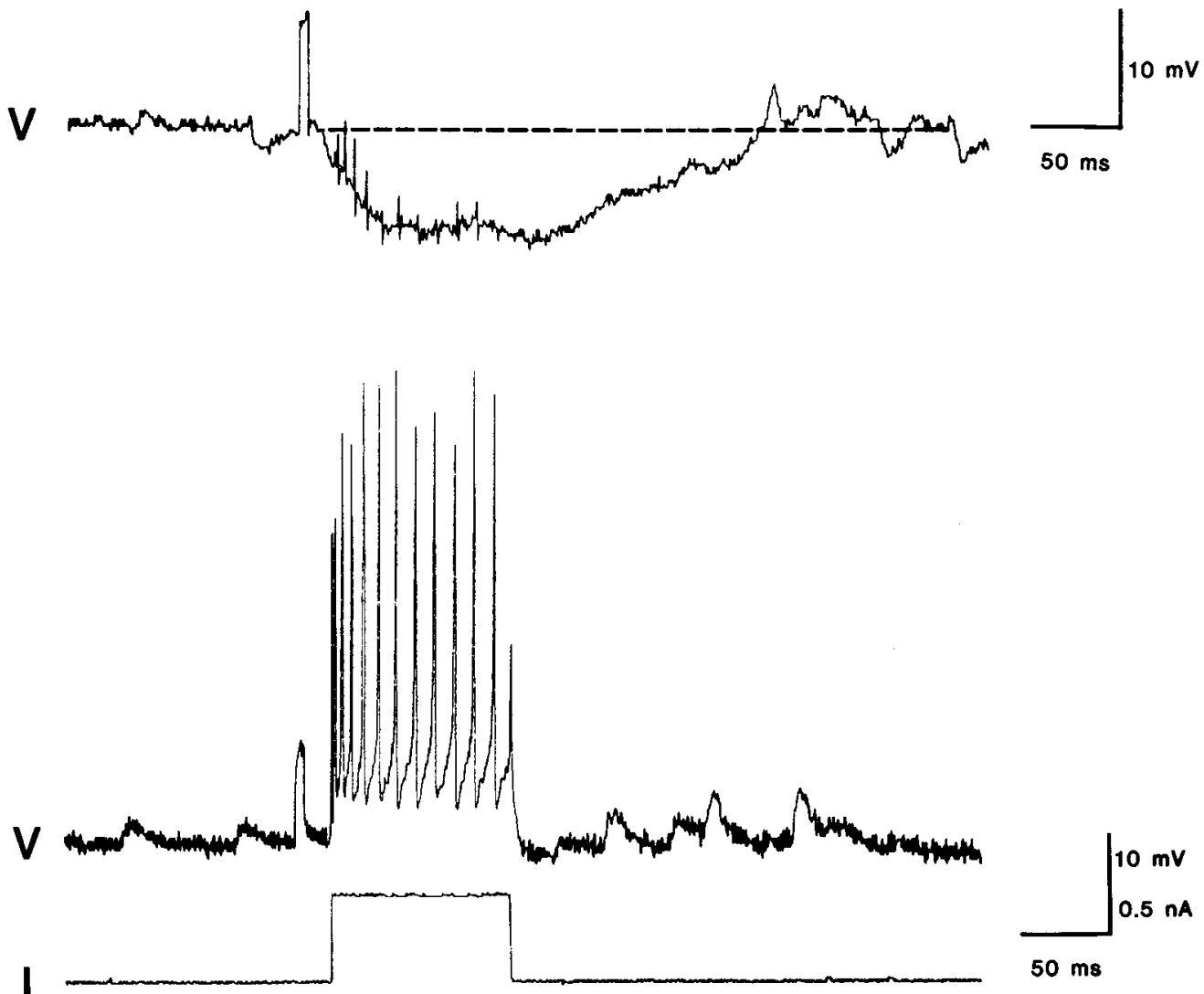

Figure 8. Inhibitory connection from an $\mathrm{O} / \mathrm{A}$ interneuron to a stratum pyramidale interneuron. Depolarization-induced firing in the $\mathrm{O} / \mathrm{A}$ interneuron (middle trace) produced a $10 \mathrm{mV}$ hyperpolarization in the stratum pyramidale interneuron (upper trace). The membrane recovered to prestimulation level (dotted line, upper trace) $125 \mathrm{msec}$ after the end of the burst in the $\mathrm{O} / \mathrm{A}$ interneuron. Stratum pyramidale interneuron RMP, $-40 \mathrm{mV} ; \mathrm{O} / \mathrm{A}$ interneuron RMP, $-80 \mathrm{mV}$

tum stimulation) in pyramidal cells. The afferent excitation of $\mathrm{O} / \mathrm{A}$ interneurons is mediated by feedforward circuitry, as shown in paired recordings; initial action potentials evoked synaptically in the $\mathrm{O} / \mathrm{A}$ interneuron consistently precede CA1 pyramidal cell action potentials (see Fig. 6). The mechanism resulting in a stronger and more rapid response in interneuron versus pyramidal cell is not clear. However, since the interneuron dendrites lack spines, there is no attenuation of synaptic current across the spine neck. Additionally, the interneuron input resistance is higher than that of the pyramidal cell; thus, there ought to be less shunting of synaptic current. These differences may result in a larger and more rapid synaptic response in the interneurons and may also account for the rather large unitary EPSPs seen in them.

We have not observed any synaptically mediated inhibitory responses onto the $\mathrm{O} / \mathrm{A}$ interneurons. The major source of inhibition appears to be the AHP observed following burst firing. Thus, the major determinant in terminating an evoked response in an $\mathrm{O} / \mathrm{A}$ interneuron appears to be the offset of the excitatory input in combination with the late AHP.

The only output connections from the $\mathrm{O} / \mathrm{A}$ interneuron we have observed were inhibitory in nature. Thus far, we have found no direct evidence for excitatory connections from interneurons to pyramidal cells (see also Knowles and Schwartzkroin, 1981). Our paired recordings indicate that stimulation of $\mathrm{O} / \mathrm{A}$ interneurons produced hyperpolarizing responses in a small number of pyramidal and nonpyramidal cells. The reasons for the small percentage of observed interactions is not clear. Certainly, there is a sampling problem, which is compounded by the relatively large distance between $\mathrm{O} / \mathrm{A}$ cells and pyramidal cell layer $(300 \mu \mathrm{m})$. There may also be a significant degree of "disconnection" between $\mathrm{O} / \mathrm{A}$ interneurons and pyramidal cells, perhaps because of slice-induced damage (i.e., tissue slicing severs critical connections).

Given that interneurons at the $\mathrm{O} / \mathrm{A}$ border contain SRIF, and may therefore use it as a neurotransmitter, it is possible that the $\mathrm{O} / \mathrm{A}$ interneuron-to-pyramidal cell interactions we observed were mediated by SRIF. Yet, it is not clear what the action of SRIF is on pyramidal cells. Both direct excitatory (Dodd and Kelly, 1978; Mueller et al., 1986) and inhibitory (Pittman and Siggins, 1981) actions have bcen reported. Our failure to observe intrinsic excitatory interactions and our occasional observation of postsynaptic inhibitory responses suggest an endogenous inhibitory action of SRIF. However, since many of the SRIFpositive cells also contain GABA (Somogyi et al., 1984), it is also possible that the small number of inhibitory interactions were mediated by GABA release. The inhibitory interactions we observed were similar to those observed between basket cells and pyramidal cells, interactions thought to be produced by GABAergic mechanisms (Knowles and Schwartzkroin, 1981).

In one recorded pair of cells, the local synaptic interaction between an $\mathrm{O} / \mathrm{A}$ interneuron and $\mathrm{CA} 1$ pyramidal cell was reciprocal. Stimulation of the pyramidal cell strongly excited the $\mathrm{O} / \mathrm{A}$ interneuron directly; stimulation of the $\mathrm{O} / \mathrm{A}$ interneuron 


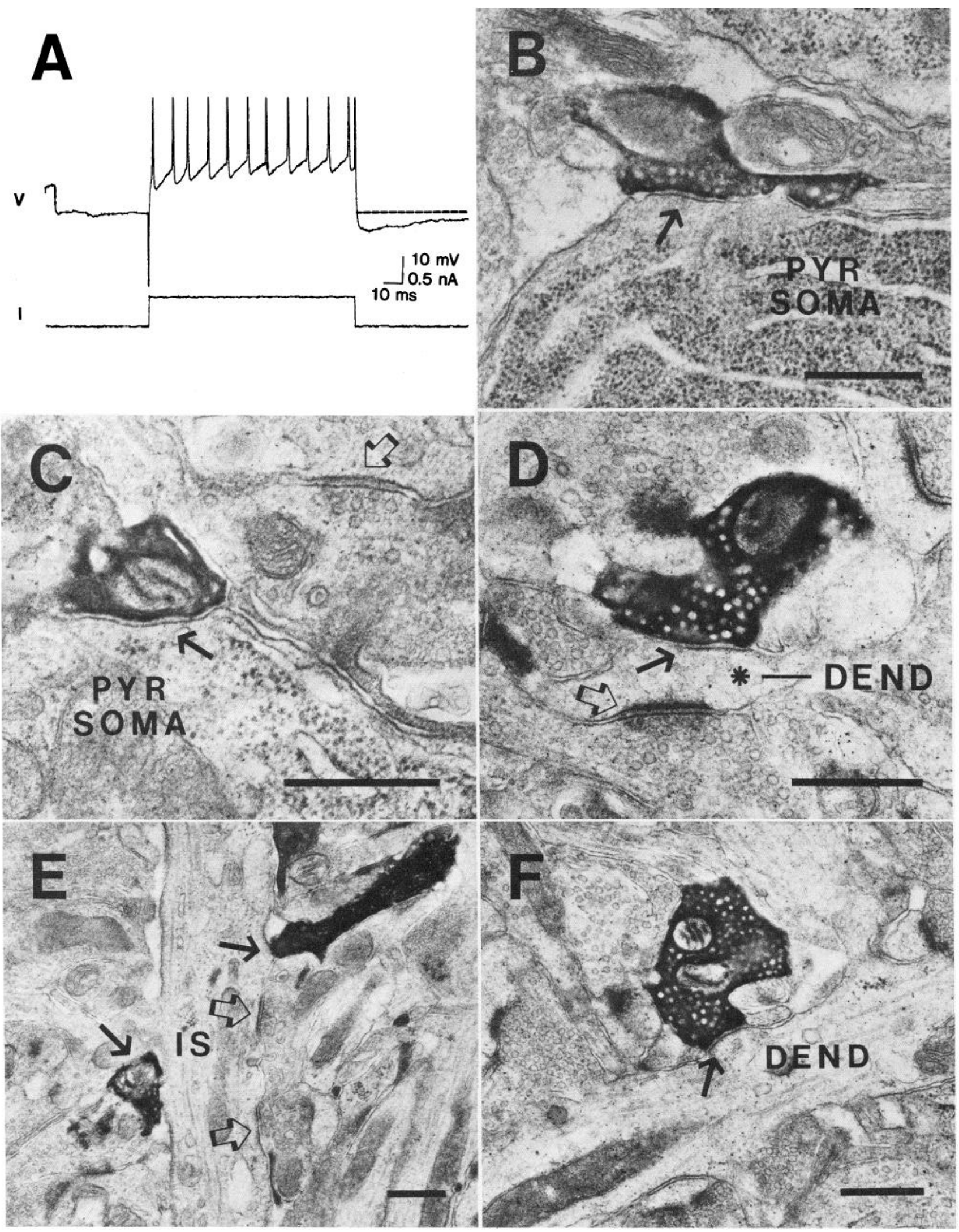

Figure 9. HRP-filled O/A interneuron. A, O/A interneuron response to depolarizing current prior to HRP injection. An intrasomatic depolarizing current pulse $(0.5 \mathrm{nA}, 100 \mathrm{msec}$; lower trace) produces a train of action potentials (upper trace) typical of the O/A interneurons. Note the AHP following the end of the burst. Dotted line is resting membrane potential. O/A interneuron RMP, $-55 \mathrm{mV}$. B, HRP-filled axonal process (arrow) contacting a pyramidal cell soma $(P Y R$ SOMA). Note the symmetric nature of the synaptic contact, especially the cleft and the thin, even postsynaptic membrane specialization. $C$, HRP-filled axonal process (arrow) contacting an individual pyramidal cell soma. A symmetric synaptic contact from 


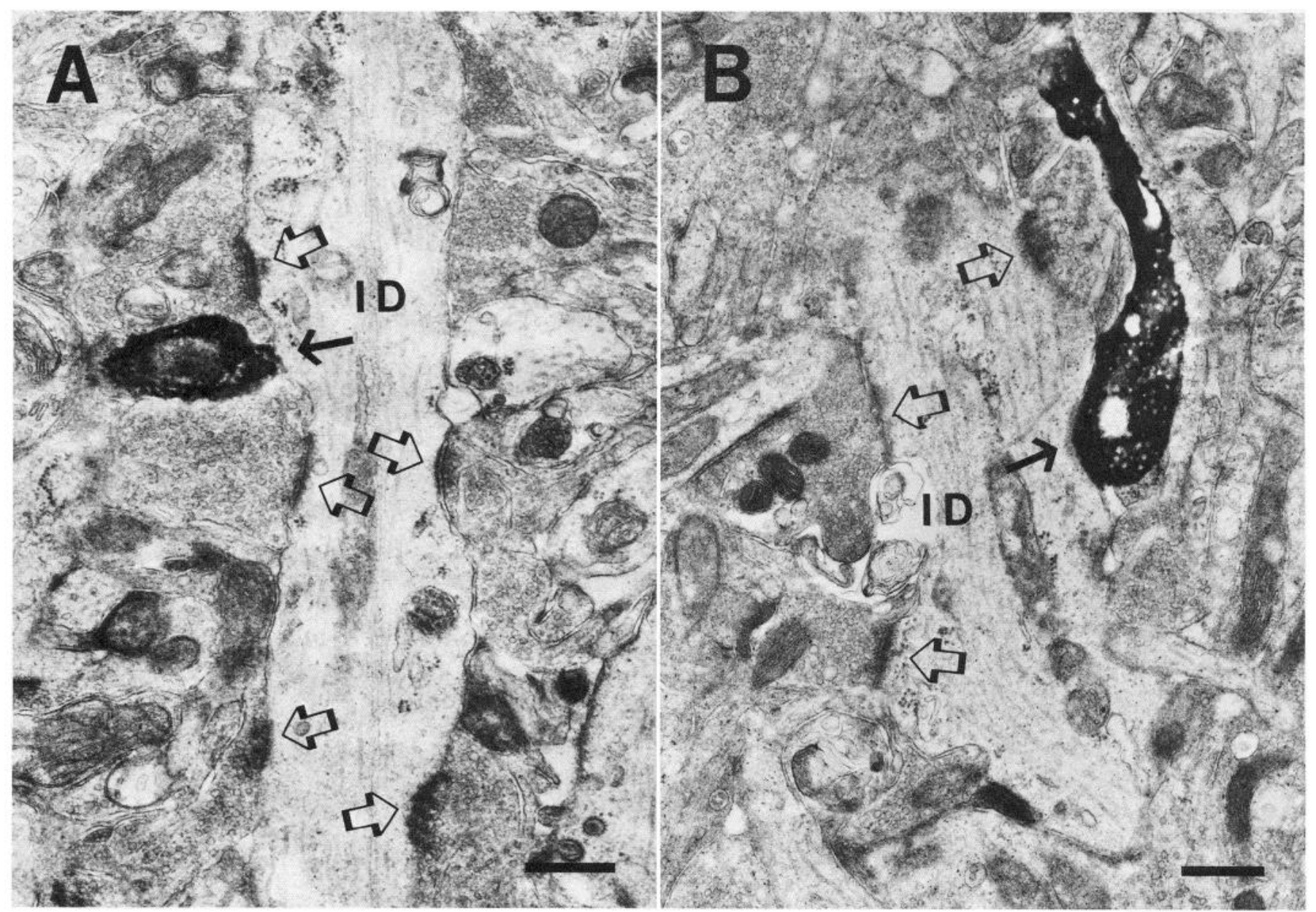

Figure 10. O/A interneuron contacts onto other interneurons. $A$ and $B$, HRP-filled axonal processes (arrows) contacting other interneuron dendrites (ID) in stratum oriens. Note numerous other, non-HRP-filled synaptic contacts (open arrows) onto the aspinous interneuron dendrites. Scale bar, $0.5 \mu \mathrm{m}$.

produced a small hyperpolarization of the pyramidal cell. This hyperpolarization was sufficient to inhibit the firing of the pyramidal cell, suggesting that some $\mathrm{O} / \mathrm{A}$ interneurons may mediate weak feedback inhibition of CA1 pyramidal cells.

Our electron microscopic observations further substantiate the direct connections between $\mathrm{O} / \mathrm{A}$ interneurons and $\mathrm{CA} 1 \mathrm{py}-$ ramidal and nonpyramidal cells. In HRP-filled O/A interneurons, an axon emerged from the soma and coursed for a short distance along the alveus; it then turned perpendicularly and ascended toward stratum pyramidale. En passant and terminaux synaptic contacts, typical of type II symmetric synapses, could be identified on pyramidal cells and dendrites. Although partially obscured by the HRP dense reaction product, many synapses meet the 3 criteria for type II contacts. HRP-filled axonal processes were found throughout stratum pyramidale, where many contacts were made onto pyramidal cell somata and occasionally on their initial segments. In stratum oriens, symmetric synaptic contacts were made with basal dendrites of the pyramidal cells. HRP-filled axons of O/A interneurons also made contacts with nonpyramidal cell dendrites in stratum oriens.

The formation by $\mathrm{O} / \mathrm{A}$ terminals of exclusively symmetric synaptic contacts (which are characteristic of inhibitory synapses) on pyramidal cells and pyramidale interneurons supports our electrophysiological observations of inhibitory connections from $\mathrm{O} / \mathrm{A}$ interneurons to $\mathrm{CA} 1$ pyramidal and nonpyramidal cell types.

\section{Circuitry of CA1 region}

We have summarized in Figure 11 our current view of the local circuitry of the CA1 region based on our intracellular recordings from these neurons (Schwartzkroin and Mathers, 1978; Knowles

another cell (not filled with HRP) is also present on an adjacent pyramidal cell (open arrow). D, Another HRP-filled interneuron axonal process making an apparent symmetric synaptic contact (arrow) with a pyramidal cell basal dendrite (*-DEND). In contrast, note the asymmetric synaptic contact on the same dendrite (open arrow). E. Pyramidal cell initial segment (IS) with 2 HRP-filled axonal contacts (arrows). Other symmetric synaptic contacts (from non-HRP terminals) appear in the same vicinity (open arrows). $F$, HRP-filled interneuron axonal process forming another apparently symmetric synaptic contact (arrow) with a pyramidal cell basal dendrite $(D E N D)$ in stratum oriens. Scale bars, $0.5 \mu \mathrm{m}(B-F)$. 

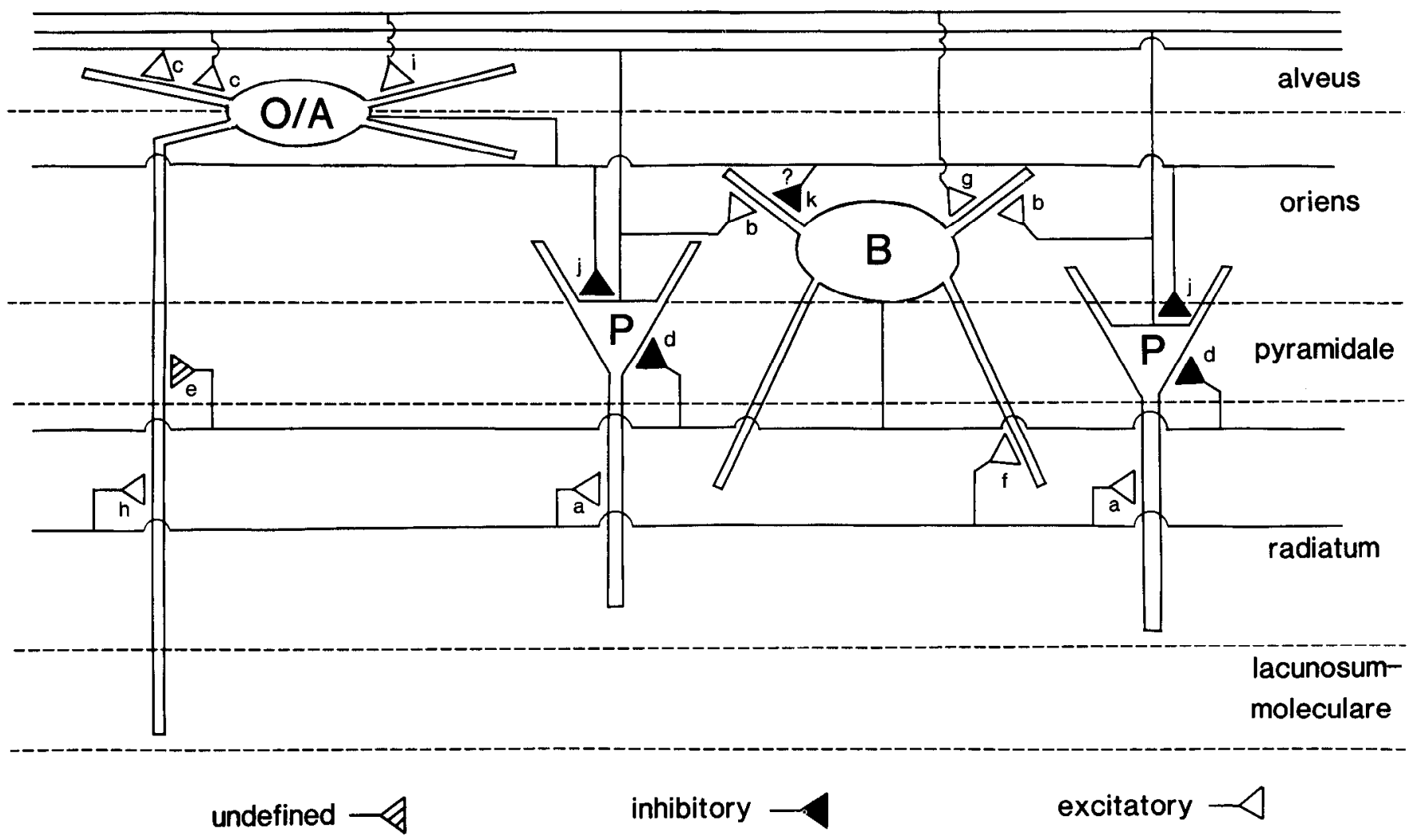

Figure 11. Diagram representing the intrinsic circuitry of the CA1 region as deduced from our intracellular studies from pyramidal cells $(P)$, basket cells $(B)$, and oriens/alveus interneurons $(\mathrm{O} / \mathrm{A})$. See text for details.

and Schwartzkroin, 1981; present data). For simplicity, only 2 pyramidal cells, a basket cell, and an O/A interneuron are represented, and afferent connections onto pyramidal basal dendrites are omitted. Afferents in stratum radiatum make excitatory synapses (synapse a) on apical dendrites of pyramidal cells. Collaterals of pyramidal cell axon, in turn, make excitatory synapses on basket cells (synapse b) and on O/A interneurons (synapse c). Basket cells also receive excitatory synapses from afferent fibers in stratum radiatum (synapse f) and from other afferents in the alveus (synapse g). Collaterals of the basket cell axon make inhibitory connections with pyramidal cells (synapse d) and produce a still undefined effect on $\mathrm{O} / \mathrm{A}$ interneurons (synapse e). The $\mathrm{O} / \mathrm{A}$ interneuron receives excitatory synapses from pyramidal cell collaterals (synapse c), from afferent fibers in stratum radiatum (synapse h), and from afferent fibers in the alveus (synapse i). In turn, the axon of the $\mathrm{O} / \mathrm{A}$ interneuron makes inhibitory synapses with pyramidal cells (synapse $\mathrm{j}$ ) and (perhaps) with basket cells (synapse k). The rapid and powerful excitatory synapses on $\mathrm{O} / \mathrm{A}$ interneurons and basket cells in stratum radiatum result in these interneurons being excited before the pyramidal cells (i.e., feedforward excitation). Thus, the evidence so far available suggests that both types of interneurons, basket cells and $\mathrm{O} / \mathrm{A}$ interneurons, mediat $\cdot$ feedforward as well as feedback inhibition of CA1 pyramidal cells. Since the dendritic processes of the $\mathrm{O} / \mathrm{A}$ interneurons arborize in the alveus, but the basket cell processes do not, these 2 feedforward inhibitory systems may be under the control of different afferent projections.

\section{References}

Algcr, B. E., and R. A. Nicoll (1979) GABA-mediated biphasic inhibitory responses in hippocampus. Nature 281: 315-317.

Amaral, D. G. (1978) A Golgi study of cell types in the hilar region of the hippocampus in the rat. J. Comp. Neurol. 182: 851-914.

Andersen, P., and T. Lomo (1966) Mode of activation of hippocampal pyramidal cells by excitatory synapses on dendrites. Exp. Brain Res. 2: $247-260$

Andersen, P., B. Holmqvist, and P. E. Voorhoeve (1966) Entorhinal activation of dentate granule cells. Acta Physiol. Scand. 66: 448-466.

Andersen, P., T. V. P. Bliss, and K. K. Skrede (1971) Lamellar organization of hippocampal excitatory pathways. Exp. Brain Res. 13: 222-238.

Andersen, P., B. H. Bland, and J. D. Dudar (1973) Organization of the hippocampal output. Exp. Brain Res. 17: 152-168.

Bakst, I., J. H. Morrison, and D. G. Amaral (1985) The distribution of somatostatin-like immunoreactivity in the monkey hippocampal formation. J. Comp. Neurol. 236: 423-442.

Blackstad, T. W., K. Brink, J. Hem, and B. Jeune (1970) Distribution of hippocampal mossy fibers in the rat. An experimental study with silver impregnation methods. J. Comp. Neurol. 138: 433-450.

Dodd, J., and J. S. Kelly (1978) Is somatostatin an excitatory transmitter in the hippocampus? Nature 273: 674-675.

Frotscher, M., Cs. Leranth, K. Lubbers, and W. H. Oertel (1984) Commissural afferents innervate glutamate decarboxylase immunoreactive non-pyramidal neurons in the guinea pig hippocampus. Neurosci. Lett. 46: 137-143.

Hjorth-Simonsen, A. (1973) Some intrinsic connections of the hippocampus in the rat: An experimental analysis. J. Comp. Neurol. 147: $145-162$.

Knowles, W. D., and P. A. Schwartzkroin (1981) Local circuit synaptic interactions in hippocampal brain slice. J. Neurosci. 1 : 318-322.

Kohler, C., and V. Chan-Palay (1982) Somatostatin-like immuno- 
reactive neurons in the hippocampus: An immunocytochemical study in the rat. Neurosci. Lett. 34: 259-264.

Kunkel, D. D., A. E. Hendrickson, J.-Y. Wu, and P. A. Schwartzkroin (1986) Glutamic acid decarboxylase (GAD) immunocytochemistry of developing rabbit hippocampus. J. Neurosci. 6: 541-552.

Lomo, T. (1971) Patterns of activation in a monosynaptic cortical pathway: Perforant path input to the dentate area of the hippocampal formation. Exp. Brain Res. 12: 18-45.

Lorente de No, R. (1934) Studies on the structure of the cerebral cortex. II. Continuation of the study of the ammonic system. J. Psychol. Neurol. (Lpz.) 46: 113-177.

Morrison, J. H., R. Benoit, P. J. Magistreth, N. Ling, and F. E. Bloom (1982) Immunocytochemical distribution of pro-somatostatin-related peptides in hippocampus. Neurosci. Lett. 34: 137-142.

Mueller, A. L., J. S. Taube, and P. A. Schwartzkroin (1984) Development of hyperpolarizing inhibitory postsynaptic potentials and hyperpolarizing response to gamma-aminobutyric acid in rabbit hippocampus studied in vitro. J. Neurosci. 4: 860-867.

Mueller, A. L., D. D. Kunkel, and P. A. Schwartzkroin (1986) Electrophysiological actions of somatostatin (SRIF) in hippocampus: An in vitro study. Cell. Mol. Neurobiol. 6: 363-379.

Pittman, Q. J., and G. R. Siggins (1981) Somatostatin hyperpolarizes hippocampal pyramidal cells in vitro. Brain Res. 221: 402-408.

Ramon y Cajal, S. (1911) Histologie du Systeme Nerveux de l'Homme et des Vertebres, Maloine, Paris.

Redman, S., and B. Wamsley (1983) Amplitude fluctuations in synaptic potentials evoked in cat spinal motoneurons at identified group Ia synapses. J. Physiol. (Lond.) 343: 135-145.

Ribak, C. E., and L. Anderson (1980) Ultrastructure of the pyramidal basket cells in the dentate gyrus of the rat. J. Comp. Neurol. 192: 903-916.

Ribak, C. E., J. E. Vaughn, and K. Saito (1978) Immunocytochemical localization of glutamic acid decarboxylase in neuronal somata following colchicine inhibition of axonal transport. Brain Res. 140:315332.
Roberts, G. W., P. L. Woodhams, J. M. Polak, and T. J. Crow (1984) Distribution of neuropeptides in the limbic system of the rat: The hippocampus. Neuroscience 11: 35-77.

Schwartzkroin, P. A. (1975) Characteristics of CAl neurons recorded intracellularly in the hippocampal in vitro slice preparation. Brain Res. 85: 423-436.

Schwartzkroin, P. A. (1982) Development of rabbit hippocampus: Physiology. Dev. Brain Res. 2: 469-486.

Schwartzkroin, P. A., and D. D. Kunkel (1985) Morphology of identified interneurons in the CAl regions of guinea pig hippocampus. J. Comp. Neurol. 232: 205-218.

Schwartzkroin, P. A., and L. H. Mathers (1978) Physiological and morphological identification of a nonpyramidal hippocampal cell type. Brain Res. 157: 1-10.

Somogyi, P., A. J. Hodgson, A. D. Smith, M. G. Nunzi, A. Gorio, and J. Y. Wu (1984) Different populations of GABAergic neurons in the visual cortex and hippocampus of cat contain somatostatin- or cholecystokinin-immunoreactive material. J. Neurosci. 4: 2590-2603.

Somogyi, P., M. G. Nunzi, A. Gorio, and A. D. Smith (1983) A new type of specific interneuron in the monkey hippocampus forming synapses exclusively with the axon initial segments of pyramidal cells. Brain Res. 259: 137-142.

Stewart, W. W. (1978) Functional connections between cells as revealed by dye-coupling with a highly fluorescent naphthalimide tracer. Cell 14: 741-759.

Stewart, W. W. (1981) Lucifer dyes-highly fluorescent dyes for biological tracing. Nature 292: 17-21.

Swanson, L. W., and W. M. Cowan (1977) An autoradiographic study of the efferent connections of the hippocampal formation in the rat. J. Comp. Neurol. 172: 49-84.

Whittaker, V. P., and E. G. Gray (1962) The synapse: Biology and morphology. Brain Med. Bull. 18: 223-228.

Wong, R. K. S., D. A. Prince, and A. I. Basbaum (1979) Intradendritic recordings from hippocampal neurons. Proc. Natl. Acad. Sci. USA 76: $986-990$. 